Brit. J. industr. Med., 1963, 20, 118.

\title{
DUST AND FIBROSIS IN THE LUNGS OF COAL-WORKERS FROM THE WIGAN AREA OF LANCASHIRE
}

\author{
BY \\ R. SPINK* and G. NAGELSCHMIDT \\ From the Department of Pathology, Wigan Royal Infirmary, and the Ministry of Power, \\ Safety in Mines Research Establishment, Sheffield
}

(RECEIVED FOR PUBLICATION OCTOBER 23, 1962)

\begin{abstract}
During the years 1953 to 1957 more than 1,000 lungs of coal-workers in the Wigan area were examined and compared with lungs from workers in South Wales. The Wigan lungs in general appeared to be less dusty and progressive massive fibrosis less frequent than in the South Wales lungs. Also, the more advanced cases of progressive massive fibrosis appeared to be of a silicotic type.

Of these lungs, 100 were selected for study of the relation of the type and severity of pneumoconiosis to right ventricular hypertrophy, using Gough-Wentworth sections. The remaining tissues from 47 of these lungs were used for an analysis of the content and composition of the dust and its relation to the grade of fibrosis. The average coal and quartz percentages of the dust from the lungs in the Wigan area were similar to previous findings in lungs from the Cumberland coalfield but differed from those in South Wales where the lung dust has a higher coal and a lower quartz percentage. Two possible explanations for this finding are discussed.
\end{abstract}

Pneumoconiosis is found in workers from all coalfields in this country, but only a few regional studies of the pathology appear to have been made outside South Wales. In Cumberland the lung dust of coalminers has, on an average, a higher proportion of rock material and less coal dust than the lung dust from South Wales, and progressive massive fibrosis is exceedingly rare (Faulds, King, and Nagelschmidt, 1959). Lung dust from Scotland seems to be similar in composition to lung dust from South Wales, and lung dust from Durham is intermediate between South Wales and Cumberland (Safety in Mines Research Establishment, 1961). The present paper describes briefly the macroscopic appearance of pneumoconiosis in coal-miners from the Wigan area of Lancashire and gives the results of 10 lung dust analyses.

\section{Source of Material}

The Department of Pathology at the Wigan Royal Infirmary receives the lungs of coal-workers who have worked in the surrounding pits. The lungs come from (1) men who were known to have suffered

*Present address: Department of Bacteriology, Western Infirmary, Glasgow. from pneumoconiosis and were under the supervision of the Pneumoconiosis Medical Panel of the Ministry of Pensions and National Insurance in Manchester; (2) men who were suspected of suffering from pneumoconiosis but in whom a diagnosis in life had not been made; and (3) miners who had died at home or in hospital from some unrelated cause and in whom it was thought pneumoconiosis might have contributed to death. Very few were miners who had died as the result of an accident.

More than 1,000 pairs of lungs were seen over a period of five years from 1953 to 1957 by one of us. From this material lungs were selected with a view to studying the effect of lung fibrosis and its associated emphysema on the size of the right heart. When it had been found at necropsy that conditions other than pneumoconiosis existed, which could reasonably be expected to affect the size of the right heart, these cases were excluded. This left only 100 pairs of lungs for the purpose of this study, and of these large-scale sections were prepared by the GoughWentworth technique. They provided many examples of the pathological changes produced by dust. A description of the chief findings, together with lung dust analyses, seemed worth while, 
particularly in view of the fact that the coal mined is of lower "rank" than in South Wales.

It was not possible to get any estimate of the dust conditions in the pits during the working lives of these colliers, and only in cases when severe lung changes were present was it found possible to get some details of their employment. From these it appeared that the collier usually entered the pits early in life at age 14, although he would not start work at the coal-face until several years later. The periods spent underground were variable, ranging from 20 to over 50 years. The colliers had done many different types of job underground, and it was often difficult to know at which they had spent most time and the number of years. It did appear, however, that the "average" collier had about 40 years' underground exposure and was likely to have spent some of his time working in rock, even if the main part of his work had been coal getting.

\section{Pathological Results}

It was found that the morbid anatomical changes did not differ in any way from the descriptions given by workers in the South Wales and other coalfields and that fibrosis could be classified into five grades in the same fashion as had been done previously by King, Maguire, and Nagelschmidt (1956) and by Faulds et al. (1959), namely: I, slight reticulation; II, reticulation; III, reticular and mixed nodulation; IV, confluent fibrosis (progressive massive fibrosis); and $\mathrm{V}$, silicotic nodulation, with

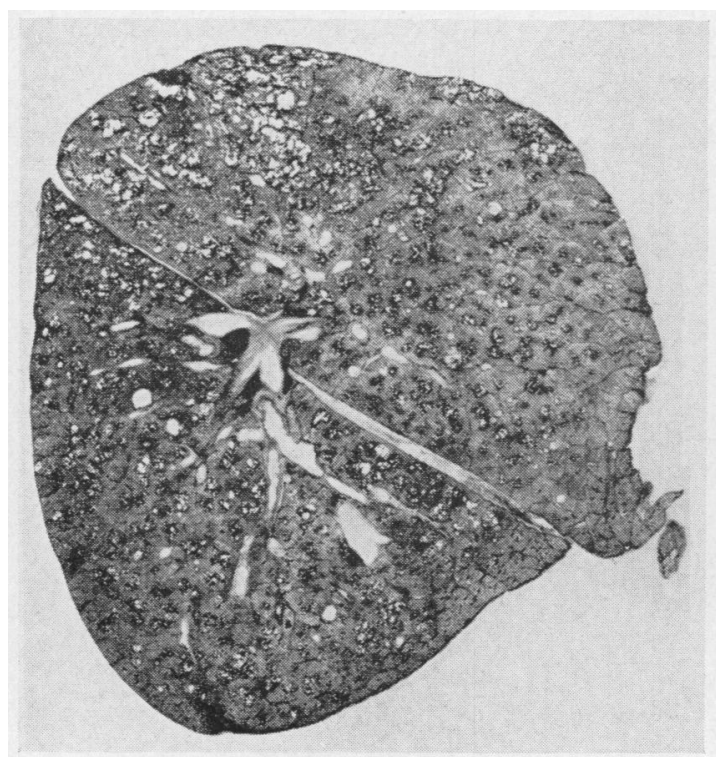

Fig. 2.-Reticulation.

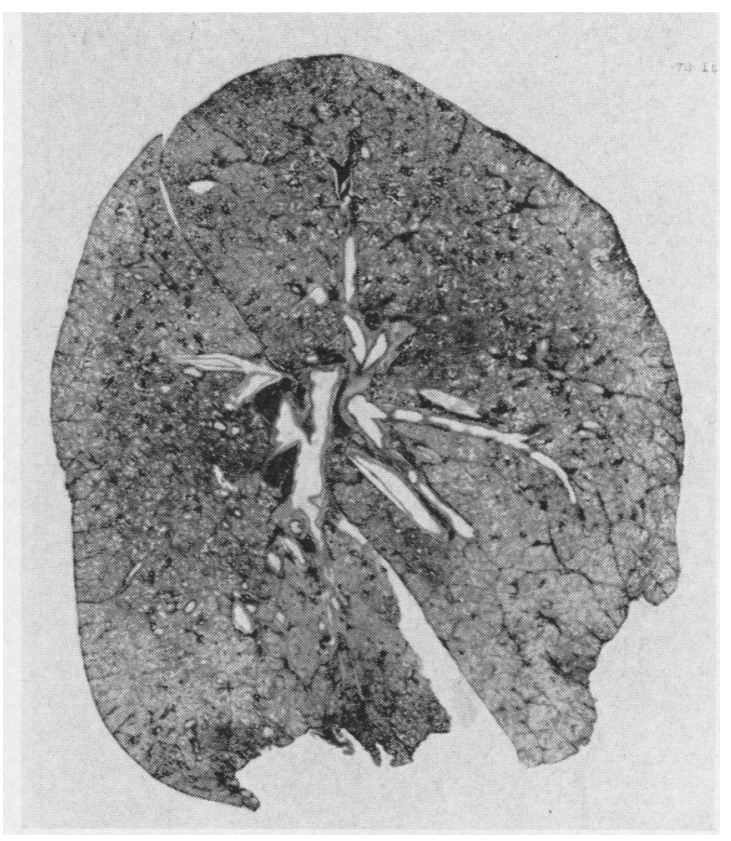

FIG. 1.-Slight reticulation.

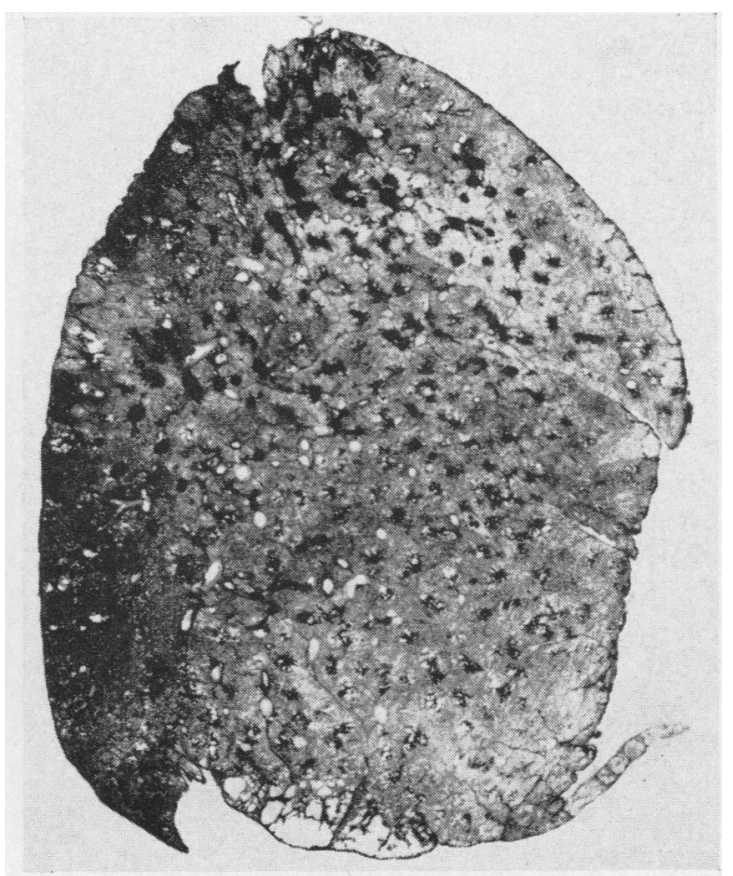

Fig. 3.-Mixed nodulation. 


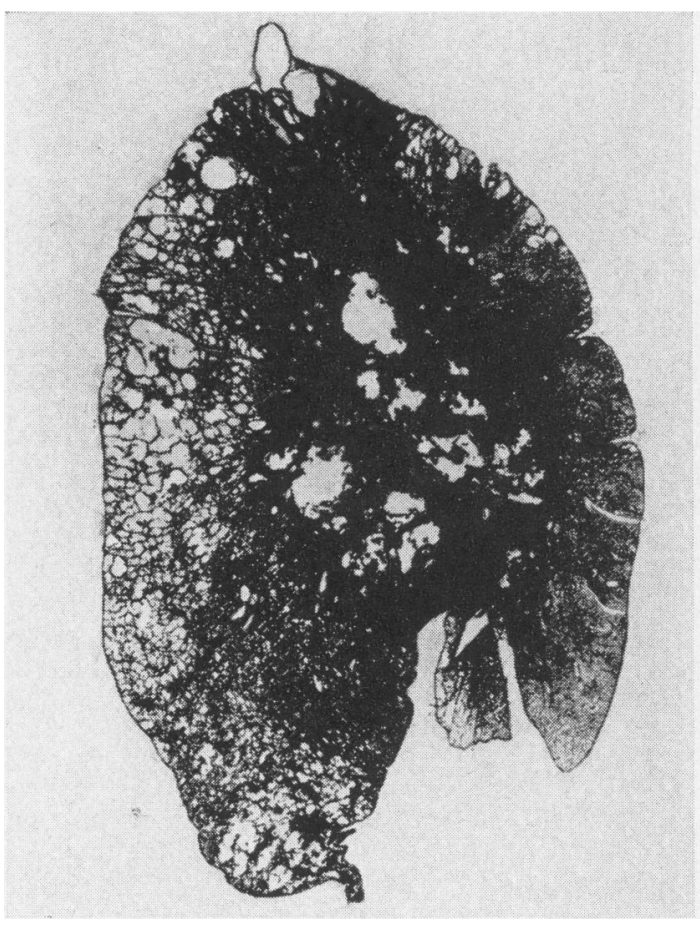

FIG. 4.-Confluent fibrosis with cavitation.

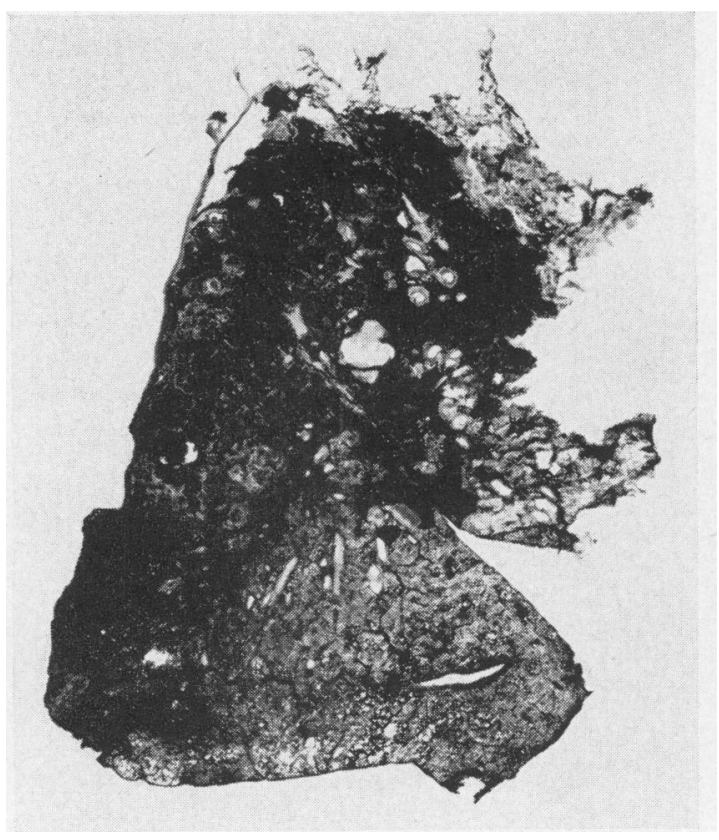

FIG. 5.-Silicotic massive fibrosis. or without confluent lesions. Figs. 1 to 5 illustrate these grades.

In surveying all the lungs seen during the five years it was observed that, in comparison with those from South Wales, there was, on the whole, much less intense dusting in the lungs, and cases of progressive massive fibrosis were much less frequent. This agrees with the first results of the National Coal Board's periodic chest radiographic examination scheme which suggests that the prevalence of all categories of pneumoconiosis is nearly twice, and that of progressive massive fibrosis three times, as high in the South-western Division as in the Northwestern Division (National Coal Board, 1961).

Although the number of lungs showing massive fibrosis in the Wigan area may not be as high as in South Wales, it was noticed that a large proportion of the lungs more severely affected with massive fibrosis showed silicosis. In some cases a mixed picture was present, but many of the lungs showed pure silicotic nodulation, most often with confluence, and in a few cases the confluence was so marked that these undoubtedly constituted the most extensive and severe cases of massive lesions.

In the series of 100 lung pairs which were studied with large sections, there were 35 showing massive fibrosis and, of these, 17 showed confluent silicosis. The information available in these cases of confluent silicosis did not always give any indication of the type of work the collier had been doing most of the time, but in the worst cases there was a history of drilling or tunnelling.

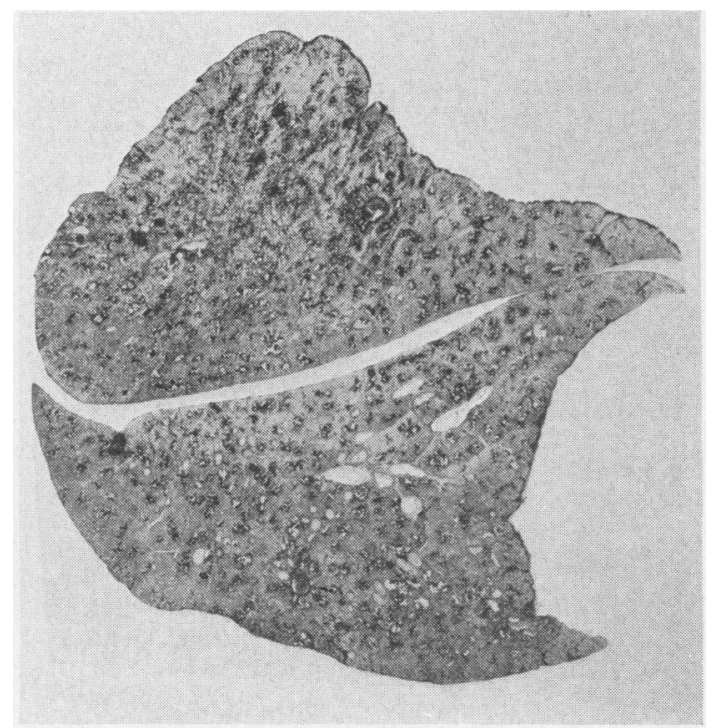

FIG. 6.-Simple pneumoconiosis with Caplan nodes. 
Amongst the 100 lungs, one (Fig. 6) showed a type of nodulation corresponding to that described by Caplan in South Wales (Caplan, 1953; Gough, Rivers, and Seal, 1955). The histological sections were reported by Professor J. Gough to show appearances characteristic of this condition. There was no history or necropsy note of rheumatoid arthritis in this case, but examples of Caplan's syndrome have been described in which this was absent. Hence it seems that the Lancashire coalfield can be included in the growing number in which this type of change has been found.

\section{Lung Dust Analyses}

The material available for lung dust analysis consisted of the parts of the lungs which had not been used for making the large sections. The weights of the individual lungs had not been recorded and so, although the composition of the lung dust could be determined accurately, its concentration could only be given as a percentage of the dried tissue. In these circumstances it did not seem worth while to analyse individual lungs, and it seemed preferable to analyse groups of lungs with similar macroscopic appearances.

The lung tissue was cut into pieces of about 2 in. $(5 \mathrm{~cm}$.) diameter, and from each group a sample of about $2 \mathrm{~kg}$. was taken for analysis. The groups chosen are listed in Table 1. The 10 groups included material from 47 lungs in all. The groups with simple pneumoconiosis, mixed nodulation, and silicotic nodulation were derived from six to eight lungs each, those with progressive massive fibrosis from three to five lungs, and finally material from two cases of silicosis with massive lesion was analysed separately. After careful sub-sampling, about 0.5 to $1 \mathrm{~kg}$. of each bulked sample and $150 \mathrm{~g}$. from the single lungs were minced, dried, ground, and analysed by the methods described previously (Rivers, Wise, King, and Nagelschmidt, 1960).

The acid-washed lung ashes contained mainly mica and quartz with occasionally minor amounts of kaolin and traces of anatase and felspar. The coal and quartz percentages of the lung dust are the main characteristic features, and these are given in Table 1 together with the total dust concentrations in the lungs. The increase in total dust for samples 1 to 3 suggests that the bulking of the lungs by inspection was reasonably efficient, but the comparatively low value for the quartz content of the silicotic nodulation sample suggests that the distinction between mixed and silicotic nodulation was meaningless.

For comparison with results from other coalfields, the 10 samples were assigned to the five grades of fibrosis described above, as shown in Table 2, and average values for dust content and composition were calculated. The lung dust concentrations of coal-workers from Lancashire, Cumberland, and South Wales (mainly from the steam coal area) for five different grades of fibrosis are given in Table 3. The data for Cumberland were taken from Faulds et al. (1959) and those for South Wales from King et al. (1956) with the addition of three lungs of silicotic rock-workers from King and Nagelschmidt (1945). The dust concentrations for fibrosis grades I to IV in all three coalfields are similar with, perhaps, a slight tendency to be higher in South Wales than in the other two divisions. It is possible

TABLE 1

DUST IN 10 LUNG SAMPLES FROM COAL-MINERS IN LANCASHIRE

\begin{tabular}{|c|c|c|c|c|c|}
\hline \multirow{2}{*}{ No. } & \multirow{2}{*}{ Description } & \multirow{2}{*}{$\begin{array}{l}\text { No. of Lungs } \\
\text { Bulked }\end{array}$} & \multirow{2}{*}{$\begin{array}{l}\text { Total Dust } \\
\text { (\% dried lung) }\end{array}$} & \multicolumn{2}{|c|}{ Total Dust } \\
\hline & & & & Coal* $(\%)$ & Quartz* $(\%)$ \\
\hline $\begin{array}{r}1 \\
2 \\
3 \\
4 \\
5 \\
6 \\
7 \\
8 \\
9 \\
10\end{array}$ & $\begin{array}{l}\text { Simple pneumoconiosis, little dust } \\
\text { Simple pneumoconiosis, medium dust } \\
\text { Simple pneumoconiosis, much dust } \\
\text { Mixed nodulation } \\
\text { Silicotic nodulation } \\
\text { Progressive massive fibrosis, no rock work } \\
\text { Progressive massive fibrosis, no history } \\
\text { Progressive massive fibrosis, rock history } \\
\text { Silicotic progressive massive fibrosis A } \\
\text { Silicotic progressive massive fibrosis B }\end{array}$ & $\begin{array}{l}6 \\
7 \\
7 \\
8 \\
6 \\
3 \\
5 \\
3 \\
1 \\
1\end{array}$ & $\begin{array}{c}2 \cdot 0 \\
4 \cdot 75 \\
6 \cdot 7 \\
6 \cdot 2 \\
6 \cdot 14 \\
8 \cdot 84 \\
11 \cdot 05 \\
7 \cdot 78 \\
7 \cdot 94 \\
9 \cdot 5\end{array}$ & $\begin{array}{l}57 \\
69 \\
46 \\
45 \\
49 \\
41 \\
42 \cdot 5 \\
31 \cdot 6 \\
24 \cdot 2 \\
23 \cdot 3\end{array}$ & $\begin{array}{l}8 \cdot 5 \\
5 \cdot 6 \\
9 \cdot 2 \\
12 \cdot 2 \\
7 \cdot 6 \\
10 \cdot 6 \\
13 \cdot 8 \\
15 \cdot 05 \\
15.6 \\
19 \cdot 6\end{array}$ \\
\hline
\end{tabular}

*The difference between 100 and the sum of the coal and quartz values consists mainly of mica and kaolin

TABLE 2

CLASSIFICATION OF FIBROSIS GRADES AND ALLOCATION OF SAMPLES FROM TABLE 1

\begin{tabular}{c|l|c}
\hline Grade of Fibrosis & Description & Samples from Table 1 \\
\hline I & Slight reticulation & Reticulation \\
III & Mixed nodulation & 2 and 3 \\
IV & Massive fibrosis & 5 \\
V & Silicotic nodulation, including massive lesions & 6 \\
\hline
\end{tabular}


TABLE 3

LUNG DUST CONCENTRATIONS FOR FIVE GRADES OF FIBROSIS IN THREE COALFIELDS

\begin{tabular}{|c|c|c|c|c|c|c|}
\hline \multirow{2}{*}{$\begin{array}{l}\text { Grade of } \\
\text { Fibrosis }\end{array}$} & \multicolumn{3}{|c|}{ Total Dust $\%$ Dried Lung in } & \multicolumn{3}{|c|}{ No. of Lungs in } \\
\hline & Lancs. & Cumberland & S. Wales & Lanzs. & Cumberland & S. Wales \\
\hline $\begin{array}{l}\text { I } \\
\text { II } \\
\text { III } \\
\text { IV } \\
\text { V }\end{array}$ & $\begin{array}{r}2 \cdot 0 \\
5 \cdot 7 \\
6 \cdot 2 \\
10 \cdot 2 \\
8 \cdot 2\end{array}$ & $\begin{array}{l}2 \cdot 3 \\
4 \cdot 2 \\
6 \cdot 3 \\
7 \cdot 4\end{array}$ & $\begin{array}{r}3.8 \\
5.8 \\
9.7 \\
13.0 \\
5.0\end{array}$ & $\begin{array}{r}6 \\
14 \\
14 \\
8 \\
5\end{array}$ & $\begin{array}{r}6 \\
16 \\
5 \\
6\end{array}$ & $\begin{array}{r}11 \\
20 \\
20 \\
19 \\
4\end{array}$ \\
\hline
\end{tabular}

that the dust concentration in the Wigan lungs would have been slightly higher if whole lungs had been analysed instead of the remainder after removal of central slices. But it does seem unlikely that the dust composition would have been altered by this sampling procedure.

Values for the dust composition in the three coalfields are given in Table $4^{*}$. The quartz percentages of the Lancashire lung dust are slightly higher for fibrosis grades I to IV than those from Cumberland and much higher than those from South Wales. The

TABLE 4

LUNG DUST COMPOSITION FOR FIVE GRADES OF FIBROSIS IN THREE COALFIELDS

\begin{tabular}{|c|c|c|c|c|c|c|}
\hline \multirow{2}{*}{$\begin{array}{l}\text { Grade of } \\
\text { Fibrosis }\end{array}$} & \multicolumn{2}{|c|}{ Lancashire } & \multicolumn{2}{|c|}{ Cumberland } & \multicolumn{2}{|c|}{ South Wales } \\
\hline & $\begin{array}{c}\text { Coal } \\
(\%)\end{array}$ & $\begin{array}{c}\text { Quartz } \\
(\%)\end{array}$ & $\begin{array}{l}\text { Coal } \\
(\%)\end{array}$ & $\underset{(\%)}{\text { Quartz }}$ & $\begin{array}{l}\text { Coal } \\
(\%)\end{array}$ & $\underset{(\%)}{\text { Quartz }}$ \\
\hline $\begin{array}{l}\text { I } \\
\text { II } \\
\text { III } \\
\text { IV } \\
\text { V }\end{array}$ & $\begin{array}{l}57 \\
58 \\
47 \\
42 \\
28\end{array}$ & $\begin{array}{r}8.5 \\
7.4 \\
10.0 \\
12.6 \\
14.1\end{array}$ & $\begin{array}{l}67 \\
53 \\
55 \\
21\end{array}$ & $\begin{array}{c}3.3 \\
5.8 \\
7 \cdot 4 \\
\frac{18.7}{18.7}\end{array}$ & $\begin{array}{l}84 \\
81 \\
80 \\
78 \\
22\end{array}$ & $\begin{array}{r}3.7 \\
4 \cdot 1 \\
4.3 \\
4.4 \\
17.6\end{array}$ \\
\hline
\end{tabular}

Numbers of lungs are the same as in Table 3.

coal percentages of the lung dusts are considerably higher for fibrosis grades I to IV in South Wales than in the other two regions. In the dried lungs with progressive massive fibrosis (grade IV fibrosis) there was about $4 \%$ coal for the Wigan lungs as against $11 \%$ for the South Wales lungs.

In Table 5 average values for coal and quartz percentages of the lung dust from the Wigan area of Lancashire, from Cumberland, and mainly from the steam coal area of South Wales are given together with the standard errors of the mean values. The lung dust composition was not significantly different between Lancashire and Cumberland but both differed significantly from South Wales in having more quartz and less coal.

*The quartz percentages for the South Wales lungs given in Table 4 are $25 \%$ lower than those given by King et al. (1956). At that time the Geiger-Müller counter $x$-ray technique (Gordon and Harris, 1956) had not yet been developed and a combination based on visual film estimates and chemical silica analyses had been used. In the meantime, 14 of the old lungs have been re-analysed, and it was found that the old quartz values were, on average, $25 \%$ too high when compared with the Geiger-Müller results.
TABLE 5

AVERAGE LUNG DUST COMPOSITION IN THREE COALFIELDS

\begin{tabular}{l|c|c|c}
\hline & $\begin{array}{c}\text { Lancashire } \\
\text { (Wigan area) }\end{array}$ & Cumberland & $\begin{array}{c}\text { South Wales } \\
\text { (mainly } \\
\text { steam coal } \\
\text { area) }\end{array}$ \\
\hline No. of lungs & 47 & 33 & 74 \\
Mean coal \% dust & 48.5 & 49.8 & $77 \cdot 2$ \\
Standard error of mean & 3.6 & 3.8 & 2.2 \\
Mean quartz \% dust & 10.2 & 8.0 & 4.9 \\
Standard error of mean & 1.0 & 1.0 & 0.5 \\
\hline
\end{tabular}

\section{Comment}

Concentration and composition of the lung dust of coal-workers from the Wigan area of Lancashire were found to be similar for any given grade of fibrosis to the values found in coal-workers from Cumberland, but the dust composition differed from that found in South Wales lungs in showing more rock dust and less coal dust. This last observation can be interpreted in two different ways, either the composition of the air-borne dust showed the same differences between Wigan and South Wales during the years in which the dust accumulated, or the airborne dust in the Wigan area contained more coal than the lung dust but due to some factor associated with the lower rank of this coal it accumulated in the lungs at a lower rate than the rock material. The coal rank code in the Wigan area ranges from 500 to 900 , the volatile matter from 32 to $40 \%$ dry ash-free coal. Corresponding values for Cumberland are coal rank code 500 to 600 with 30 to $37 \%$ volatile matter.

There is as yet no direct evidence that coal of low rank accumulates less readily in the lungs than coal of high rank, but it is quite likely that the air-borne dust in the Wigan area contained a higher proportion of rock material than in the South Wales steam coal area. In Wigan the ground is heavily faulted and cutting in dirt is common; mechanization started earlier but dust control later than in South Wales. Many of the pits are very deep, a considerable amount of work in rock is necessary to reach the seams, and the amount of rock drilling and blasting is said to have been high. It seems likely therefore 
that the difference in lung dust composition between Wigan and South Wales reflects a corresponding difference in the composition of the air-borne dusts. However, further research is required to establish whether or not coal of low rank is as readily taken up or retained in the lungs as coal of high rank.

If the first hypothesis is true, then the lung dust analyses suggest that, in contrast to South Wales, rock dust as well as coal dust has been a major hazard to which the coal-miners in the Wigan area of Lancashire have been exposed during the past 30 years.

Thanks are due to the Manchester Pneumoconiosis Medical Panel and to Dr. J. Schrager for help in this work, to Mr. N. Lambert for statistical help, and to Professor J. Gough for helpful advice and criticism.

\section{REFERENCES}

Caplan, A. (1953). Thorax, 8, 29.

Faulds, J. S., King, E. J., and Nagelschmidt, G. (1959). Brit. J. industr. Med. 16, 43 .

Gordon, R. L., and Harris, G. W. (1956). S.M.R.E. Research Report No. 138. H.M.S.O., London.

Gough, J., Rivers, D., and Seal, R. M. E. (1955). Thorax, 10, 9.

King, E. J., Maguire, B. A., and Nagelschmidt, G. (1956). Brit. J. industr. Med., 13, 9.

and Nagelschmidt, G. (1945). Spec. Rep. Ser. med. Res. Coun. (Lond.), No. 250, p. 5. H.M.S.O., London.

National Coal Board (1961). Annual Report and Accounts for 1960, vol. 1; Report, p. 33. H.M.S.O., London.

Rivers, D., Wise, M. E., King, E. J., and Nagelschmidt, G. (1960). Brit, J industr. Med., 17, 87.

Safety in Mines Research Establishment (1961). Safety in Mines Research 1960. Thirty-ninth Annual Report. H.M.S.O.,
H. Mines London. 